\title{
Visualisasi Efek Perubahan Fungsi Lahan Menggunakan Maksimum Spanning Tree dengan Pembobot Korelasi
}

\author{
Dwi Risky Arifanti \\ Program Studi Tadris Matematika, FTIK, IAIN Palopo \\ E-mail:dwiriskya@yahoo.co.id
}

\begin{abstract}
This study aims to visualize the effect of land use change using Maximum Spanning Tree with correlation weight between variables. In addition to know the most dominant factors affect the dependent variable. Based on data of land conversion of regency in South Sulawesi on year 2014, it is found that the percentage of villages experiencing the change of non-sawah land into rice field is the dominant factor. The percentage of districts / municipalities that have villages experiencing non-sawah land conversion to rice fields of 16.77 is expected to be reduced to $8.33 \%$.
\end{abstract}

Keywords: Maximum Spanning Tree, Prim Algorithm.

\begin{abstract}
Abstrak
Penelitian ini bertujuan untuk memvisualisasikan efek perubahan fungsi lahan menggunakan Maximum Spanning Tree dengan bobot korelasi antar variable. Selain itu untuk mengetahui faktor yang paling dominan mempengaruhi variabel dependen. Berdasarkan data konversi lahan kabupaten/kota di Sulawesi Selatan padda Tahun 2014 diperoleh informasi bahwa persentase desa yang mengalami perubahan lahan non sawah menjadi sawah merupakan faktor dominan terhadap persentase desa yang mengalami perubahan. Persentase kabupaten/kota yang memiliki desa yang mengalami perubahan lahan non sawah menjadi sawah sebesar 16,77 diharapkan dapat dikurangi menjadi 8,33\%.
\end{abstract}

Kata Kunci: Maximum Spanning Tree, Algoritma Prim. 


\section{Pendahuluan}

Perkembangan laju pertumbuhan yang semakin pesat menimbulkan berbagai masalah. Permasalahan-permasalahan yang dihadapi dan menjadi kendala dalam pedesaan adalah kemiskinan penduduk, kepadatan penduduk yang meningkat, permasalahan sosial yang terus bertambah, permasalahan pemukiman, permasalahan ketersediaan lahan dan berbagai permasalahan lainnya. Khusus mengenai masalah ketersediaan lahan, pertambahan jumlah penduduk mendorong perkembangan kawasan pemukiman dan industri serta pembangunan sarana dan prasarana yang menyebabkan terjadinya penurunan luas lahan pertanian.

Ketersediaan lahan yang terbatas menyebabkan timbulnya kelangkaan lahan dan konflik penggunaan lahan, sehingga mendorong terjadinya konversi lahan. Konversi lahan pertanian terutama lahan sawah menjadi penggunaan lahan non sawah. Fenomena konversi lahan muncul seiring makin tinggi dan bertambahnya tekanan kebutuhan dan permintaan terhadap lahan, baik dari sektor pertanian maupun dari sektor non pertanian sebagai akibat dari bertambahnya penduduk dan kegiatan pembangunan.

Faktor-faktor yang mempengaruhi perubahan lahan dalam dijelaskan dalam bentuk graf. Jalur dalam graf dapat memuat informasi mengenai tingkat keeratan hubungan antar faktor. Untuk selanjutnya, konversi lahan diasumsikan sebagai variabel dependen dan faktor-faktor yang mempengaruhinya disebut variabel independen. Stuktur graf dapat menjelaskan variabel-variabel yang saling mempengaruhi dan memvisualisasikan kondisi yang terjadi pada variabel jika terjadi perubahan pada variabel yang lain. Sisi dari graf G dalam penelitian ini memuat besaran nilai korelasi. Maximum Spanning Tree menghubungkan dua variabel dengan bobot paling maksimal sehingga dapat menentukan faktor paling dominan berdasarkan nilai bobot korelasi.

Maximum Spanning Tree merupakan himpunan bagian dari graf G yang tidak memiliki siklus tetapi memiliki simpul/node seperti graf $\mathrm{G}^{1}$. Purwa

\footnotetext{
${ }^{1}$ Rinaldi Munir, Matematika Diskrit (Bandung: ITB, 2012).
} 
menggunakan metode Maximum Spanning Tree dengan Algoritma Prim untuk menetapkan status daerah tertinggal ${ }^{2}$. Selain itu, Nugraha menggunakan Algoritma Prim pada Minimum Spanning Tree dengan graf berbobot $^{3}$ dan Latifah membandingkan Algoritma Prim dan Algoritma Kruskal dalam memodelkan distribusi air ${ }^{4}$.

Studi literatur mengenai metode dan permasalahan konversi lahan diharapkan dapat mendukung tujuan penilitian yaitu memvisualisasikan efek perubahan fungsi lahan menggunakan Maximum Spanning Tree dengan bobot korelasi antar variabel. Struktur graf yang diperoleh selanjutnya digunakan untuk mengetahui faktor yang paling dominan mempengaruhi variabel dependen.

\section{Kerangka Teoretis}

Graf $G$ berisikan dua himpunan yaitu himpunan berhingga tak kosong $V(G)$ dari objek-objek yang disebut titik dan himpunan berhingga (mungkin kosong) $E(G)$ yang elemen-elemennya disebut sisi sedemikian hingga setiap elemen $e$ dalam $E(G)$ merupakan pasangan tak berurutan dari titik-titik di $V(G)$ himpunan $V(G)$ disebut himpunan titik $G$ dan himpunan $E(G)$ himpunan sisi $G$. Misalkan $u$ dan $v$ adalah dua titik di $G$ dan $e=\{u, v\}$ adalah sebuah sisi di $G$. Titik $u$ dan titik $v$ berhubungan langsung di $G$; sisi $e$ menghubungkan titik $u$ dan titik $v$ di $G$; $u$ dan $v$ titik akhir sisi $e$; sisi $e$ terkait dengan titik $v$ dan titik $u^{5}$

Pengembangan aplikasi data dalam struktur jaringan graf merepresentasikan hubungan antar variabel. Simpul/node memuat variabel

2 Ihsan Purwadi, Penerapan Bayes Network Dalam Penetapan Daerah Tertinggal (Bogor: IPB, 2009).

3 Deny Wiria Nugraha, "Aplikasi Algoritma Prim Untuk Menentukan Minimum Spanning Tree Suatu Graf Berbobot Dengan Menggunakan Pemrograman Berorientasi Objek," FORISTEK : Forum Teknik Elektro dan Teknologi Informasi 1, no. 2 (September 2011): 70-79.

${ }^{4}$ Umi Latifah and Endang Sugiharti, "Penerapan Algoritma Prim Dan Kruskal Pada Jaringan Distribusi Air PDAM Tirta Moedal Cabang Semarang," UNNES Journal of Mathematics 4, no. 1 (2015): 47-57. 2007).

${ }^{5}$ Ketut Budayasa, Teori Graph Dan Aplikasinya (Surabaya: Unesa University Press, 
yang digunakan untuk menyatakan. Sebagai contoh, penelitian terdiri dari 5 variabel inpenden maka dituliskan $\mathrm{V}=\left\{X_{1}, X_{2}, X_{3}, X_{4}, X_{5}\right\}$ dan sisi/edge $\mathrm{E}=\left\{\mathrm{e}_{1}=\left(X_{1}, X_{2}\right), \mathrm{e}_{2}=\left(X_{1}, X_{3}\right), \mathrm{e}_{3}=\left(X_{4}, X_{3}\right), \mathrm{e}_{4}=\left(X_{3}, X_{5}\right)\right\}$. Jika suatu edge dari node $X_{l}$ mengarah ke node $X_{j}$ maka $X_{l}$ disebut parent $X_{j}$ dinotasikan dengan $p a\left(X_{j}\right)$ dan $X_{j}$ disebut child dari $X_{l}$. Node yang tidak memiliki parent disebut root node, sedangkan node yang tidak memiliki child disebut leaf node 6 . Dari Gambar 1 berikut, $X_{1}$ parent dari $X_{2}$ dan $X_{3}$ dan sebaliknya $X_{2}$ dan $X_{3}$ child dari $X_{1}$. Perhatikan Gambar 1 berikut:

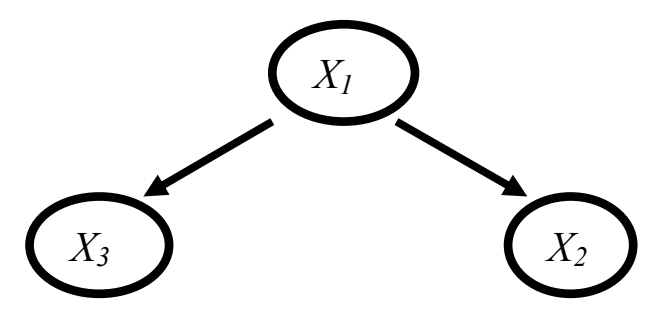

Gambar 1. Hubungan antar simpul/node

Graf berbobot merupakan graf yang setiap sisinya menyatakan nilai hubungan antar sisi (bobot). Bobot pada setiap sisi dapat berbeda-beda tergantung pada masalah yang dimodelkan dengan graf. Bobot dapat menyatakan jarak antar kota, biaya perjalanan antar kota, waktu tempuh pesan dari sebuah simpul komunikasi ke simpul komunikasi lain (dalam jaringan komputer), ongkos produksi, dan sebagainya. Selanjutnya, dalam aplikasi data, bobot tersebut menyatakan hubungan antar variabel. Sebagai contoh, dalam penelitian ini antar variabel dihubungkan menggunakan besaran nilai korelasi.

${ }^{6}$ Kevin B. Korb and Ann E. Nicholson, Bayesian Artificial Intelligence, Second Edition, 2 edition (Boca Raton, FL: CRC Press, 2010). 
Visualisasi Efek Perubahan Fungsi Lahan...

Pohon (Tree) adalah graf tak berarah terhubung yang tidak mengandung sirkuit. Pohon merentang $T$ dari suatu graf terhubung adalah suatu graf bagian dari graf $G$ yang mengandung semua simpul dari $G$ dan merupakan suatu pohon. Sisi pada suatu pohon merentang biasa disebut cabang (branch). Dan sisi di $G$ yang tidak terdapat di pohon merentang $T$ disebut tali (chord) ${ }^{7}$.

Algoritma yang dapat digunakan dalam Maximum Spanning Tree yaitu algoritma kruskal dan prim. Algoritma Prim dimulai dari graf yang kosong sama sekali. Untuk membentuk struktur Maximum Spanning Tree T dari graf G dengan algoritma Prim, mula-mula dipilih satu titik sembarang (misal $v_{1}$ ). Kemudian ditambahkan satu garis yang berhubungan dengan $v_{1}$ dengan bobot yang paling maksimum (misal $e_{1}$ ) dan titik ujung lainnya ke $T$ sehingga $T$ terdiri dari sebuah garis $e_{1}$ dan 2 buah titik-titik ujung garis $e_{1}$ (salah satunya adalah $\left.V_{1}\right)$.

\section{Metode dan Hasil Penelitian}

Sampel penelitian terdiri atas 24 kabupaten/kota di Provinsi Sulawesi Selatan yang berasal dari populasi seluruh kabupaten/kota di Indonesia. Data konversi lahan beserta faktor yang diperhatikan dalam penelitian ini berupa data sekunder pada Tahun 2014 yang diperoleh dari Badan Pusat Statistika Kota Palopo. Variabel yang digunakan dalam penelitian ini dijelaskan sebagai berikut:

Tabel 1. Variabel Penelitian

\begin{tabular}{l}
\hline Variabel Dependen \\
\hline Persentase desa yang mengalami perubahan lahan sawah menjadi lahan non \\
pertanian $(Y)$ \\
\hline Variabel Independen \\
a. Persentase desa yang mengalami perubahan lahan sawah menjadi lahan \\
pertanian non sawah $\left(X_{1}\right)$ \\
b. Persentase desa yang mengalami perubahan lahan pertanian non sawah \\
$\quad$ menjadi sawah $\left(X_{2}\right)$ \\
c. Persentase desa yang mengalami perubahan lahan pertanian non sawah \\
menjadi lahan non pertanian $\left(X_{3}\right)$ \\
d. Persentase penduduk kabupaten/kota $\left(X_{4}\right)$ \\
e. Kepadatan penduduk $\left(X_{5}\right)$
\end{tabular}

${ }^{7}$ Munir, Matematika Diskrit. 
Data penelitian dianalisis menggunakan metode Maximum Spanning Tree dengan pembobot korelasi. Tahapan metode Maximum Spanning Tree dengan pembobot korelasi dijelaskan berikut ini.

1. Mempersiapkan data

2. Menghitung korelasi antar variabel

3. Membentuk struktur Maximum Spanning Tree berdasarkan nilai korelasi pada langkah (2) menggunakan Algoritma Prim.

a. Menentukan nilai korelasi terbesar antar variabel

b. Menghubungkan kedua variabel yang diperoleh pada langkah (a) lalu menentukan arah edgenya

c. Menentukan nilai korelasi terbesar kedua antar variabel yang tersisa

d. Menghubungkan kedua variabel yang diperoleh pada langkah (c) lalu menentukan arah edgenya

e. Ulangi langkah algoritma di atas hingga nilai korelasi terkecil dengan memperhatikan aturan graf yang terbentuk bukan merupakan siklus.

\section{Struktur Maximum Spanning Tree Konversi Lahan}

Struktur Maximum Spanning Tree dibangun berdasarkan hubungan kausal variabel. Keterkaitan hubungan dalam penelitian ini berupa besaran korelasi antar variabel. Visualisasi perubahan lahan kabupaten/kota di Sulawesi Selatan menggunakan Maximum Spanning Tree dengan bobot korelasi diperoleh sebagai berikut.

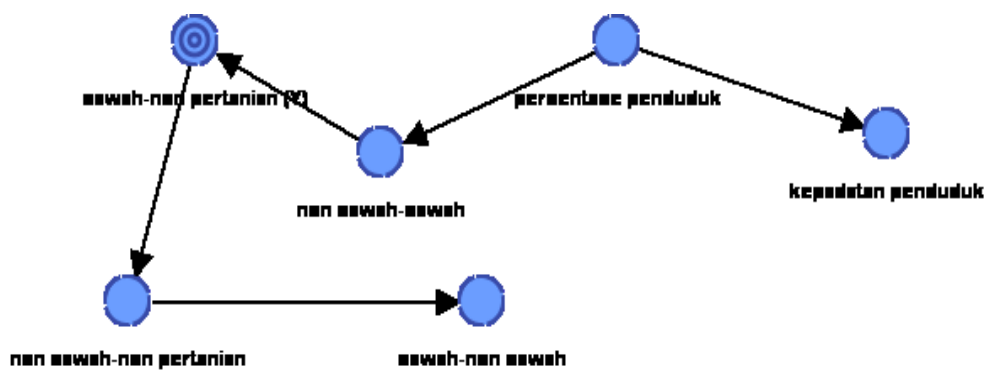

Gambar 2. Struktur faktor konversi lahan menggunakan Maximum Spanning Tree 
Berdasarkan Gambar 2. memperlihatkan bahwa persentse konversi sawah menjadi non pertanian menjadi child dari persentase konversi lahan non sawah menjadi sawah. Selain itu, persentase konversi sawah menjadi non pertanian juga merupakan parent dari variabel non sawah menjadi non pertanian. Variabel persentase penduduk menjadi parent dari variabel non sawah menjadi sawah dan variabel kepadatan penduduk.

Hubungan antar node pada struktur tersebut memberikan informasi tentang hubungan kausal antar variabel. Variabel independen yang berpengaruh langsung terhadap persentase desa yang mengalami perubahan lahan sawah menjadi lahan non pertanian adalah persentse desa yang mengalami perubahan lahan non sawah menjadi sawah. Hal ini dapat diartikan bahwa ketersediaan lahan non pertanian desa yang terdapat di kabupaten/kota Provinsi Sulawesi Selatan diperoleh dari lahan sawah yang sebelumnya berstatus lahan sawah. Selanjutnya, besaran nilai persentase desa yang mengalami perubahan lahan sawah menjadi lahan non pertanian secara tidak langsung dipengaruhi oleh persentase penduduk.

Hubungan kausal variabel dependen persentase desa yang mengalami perubahan lahan sawah menjadi lahan non pertanian terhadap variabel independen tidak hanya dapat mengetahui variabel yang mempengaruhinya tetapi juga dapat menggambarkan variabel independen yang juga dipengaruhi oleh perubahan variabel dependen. Persentase desa yang mengalami perubahan lahan sawah menjadi lahan non pertanian secara langsung mempengaruhi persentase desa yang mengalami perubahan lahan non sawah menjadi non pertanian dan secara tidak langsung mempengaruhi mempengaruhi persentase desa yang mengalami perubahan lahan sawah menjadi non pertanian.

\section{Analisis Efek Perubahan Kondisi Variabe}

Struktur jaringan Maximum Spanning Tree dengan bobot korelasi dapat menjelaskan perubahan kondisi variabel berdasarkan perubahan variabel lainnya. Perubahan kondisi variabel berupa perubahan nilai persentase 
variabel. Gambar 3 memuat informasi persentase selang kategori dari struktur graf pada Gambar 2.

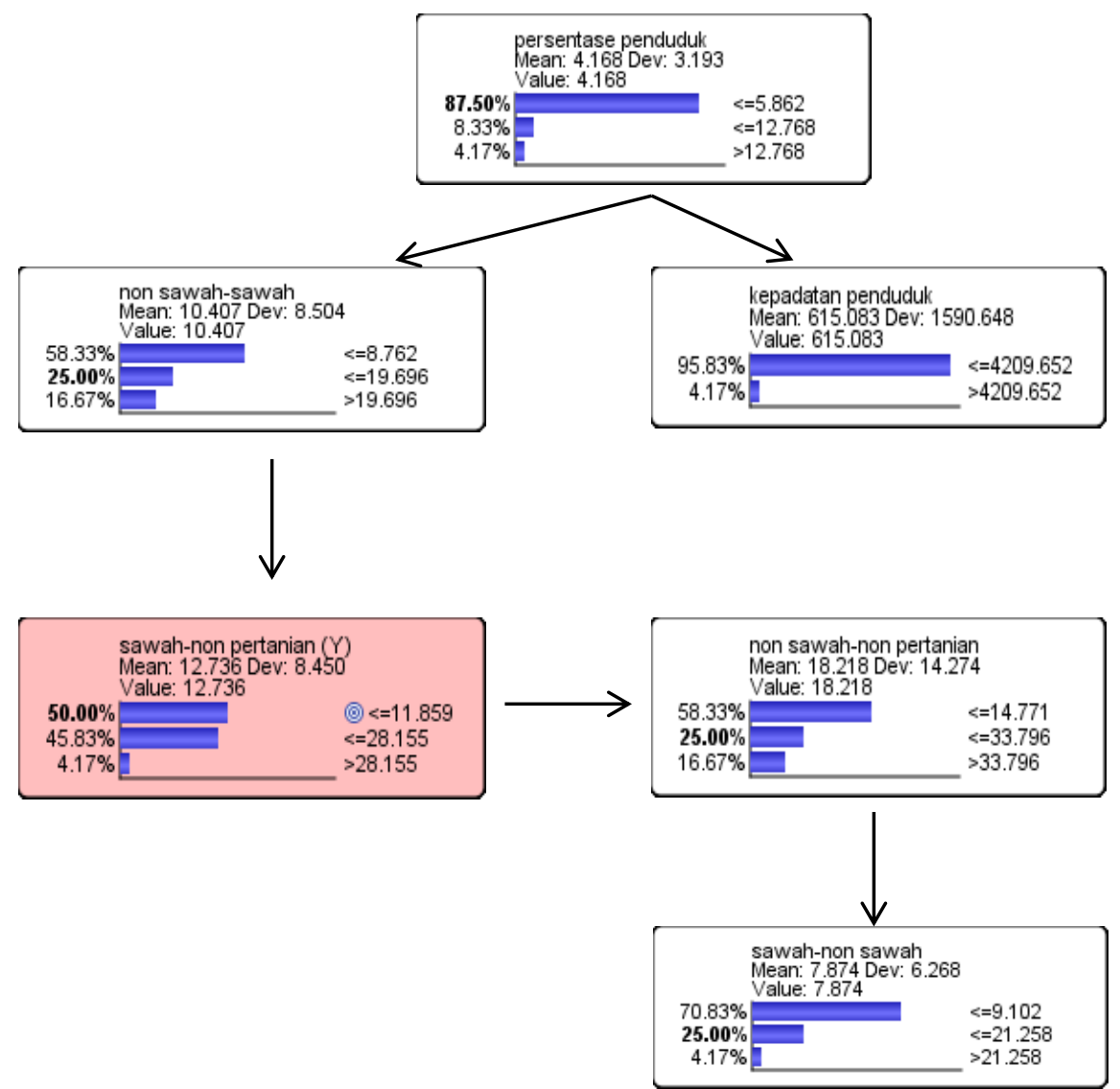

Gambar 3. Persentase kategori variabel dalam graf Maximum Spanning Tree

Kabupaten/kota di Sulawesi Selatan yang memiliki kurang dari 11,85\% desa yang mengalami perubahan lahan sawah menjadi lahan non pertanian sebanyak 50\%. Sedangkan 50\% kabupaten/kota yang lain memiliki persentase desa lebih dari 11,85\% yang mengalami perubahan lahan sawah menjadi lahan non pertanian yaitu 45,83\% kabupaten/kota di Sulawesi Selatan yang memiliki persentase desa yang mengalami perubahan lahan sawah menjadi lahan non pertanian antara $11,85 \%$ sampai $28,15 \%$ serta 4,17\% kabupaten/kota yang lain memiliki lebih dari $28,15 \%$ desa yang mengalami perubahan lahan sawah menjadi lahan non pertanian.

Persentase kabupaten/kota yang masih memiliki persentase desa yang mengalami perubahan lahan sawah menjadi lahan non pertanian masih cukup memprihatinkan. Kondisi yang diharapkan adalah menimimalkan 
persentase desa yang mengalami perubahan lahan sawah menjadi lahan non pertanian. Graf Maximum Spanning Tree pada Gambar 1 dapat digunakan untuk menentukan faktor utama yang dapat mengurangi persentase desa yang mengalami perubahan lahan sawah menjadi lahan non pertanian. Simulasi perubahan kondisi variabel dependen mengasumsikan 100\% kabupaten/kota terjadi perubahan lahan sawah menjadi non pertanian paling minimal yakni hanya 11,85\% desa. Perhatikan Gambar 4 berikut:

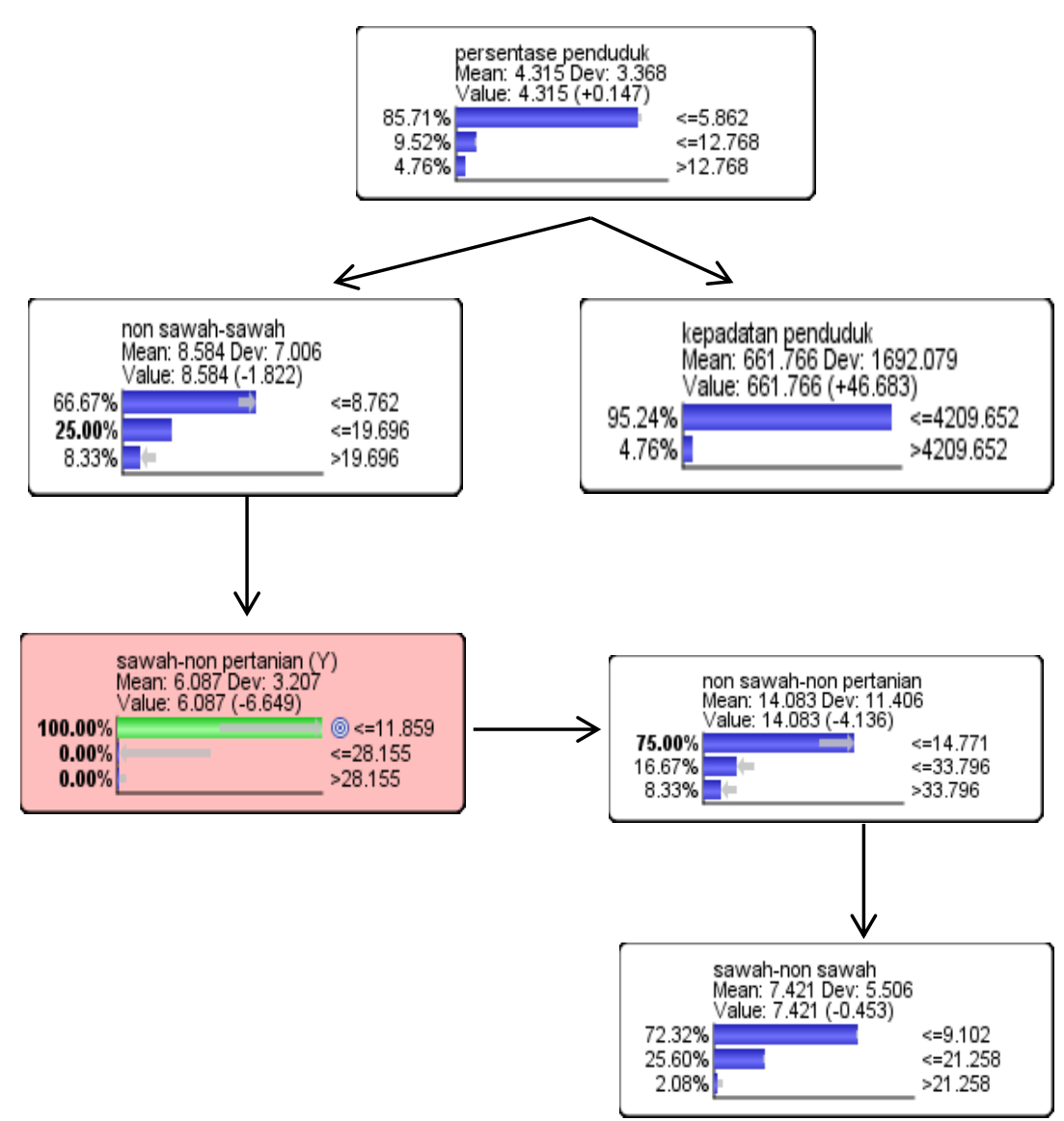

Gambar 4. Efek perubahan variabel dependen terhadap variabel independen

Perubahan persentase kabupaten/kota yang mengalami konversi sawah menjadi lahan non pertanian cukup dipengaruhi oleh kondisi konversi lahan non sawah menjadi sawah. Gambar 4 menunjukkan bahwa persentase desa yang mengalami perubahan lahan sawah menjadi lahan non pertanian dapat berkurang jika persentase kabupaten/kota yang memiliki desa yang mengalami perubahan lahan non sawah menjadi sawah dapat dikurangi. 
Dalam hal ini, persentase kabupaten/kota yang memiliki desa yang mengalami perubahan lahan non sawah menjadi sawah sebesar 16,77 diharapkan dapat dikurangi menjadi 8,33\%. Selain itu, perubahan variabel dependen tersebut dapat mengurangi persentase desa yang mengalami perubahan lahan non sawah menjadi lahan non pertanian, yakni dari $16,67 \%$ menjadi 8,33\%.

\section{Penutup}

Model graf Maximum Spanning Tree dengan bobot korelasi data konversi lahan menjelaskan bahwa persentase desa yang mengalami perubahan lahan non sawah menjadi sawah berpengaruh langsung dan merupakan faktor dominan terhadap persentase desa yang mengalami perubahan lahan sawah menjadi non pertanian. Secara tidak langsung, persentase desa yang mengalami perubahan lahan sawah menjadi non pertanian dipengaruhi oleh persentase penduduk.

Rekomendasi penelitian selanjutnya antara lain pengembangan metode graf dalam memodelkan data kontinyu persentase konversi lahan. Selain itu, diharapkan dapat mengatasi permasalahan keterbatasan data yang lebih representatif terhadap data konversi lahan misal data berupa luas lahan.

\section{Daftar Pustaka}

Budayasa, Ketut. Teori Graph Dan Aplikasinya. Surabaya: Unesa University Press, 2007.

Korb, Kevin B., and Ann E. Nicholson. Bayesian Artificial Intelligence, Second Edition. 2 edition. Boca Raton, FL: CRC Press, 2010.

Latifah, Umi, and Endang Sugiharti. "Penerapan Algoritma Prim Dan Kruskal Pada Jaringan Distribusi Air PDAM Tirta Moedal Cabang Semarang." UNNES Journal of Mathematics 4, no. 1 (2015): 47-57.

Munir, Rinaldi. Matematika Diskrit. Bandung: ITB, 2012.

Nugraha, Deny Wiria. "Aplikasi Algoritma Prim Untuk Menentukan Minimum Spanning Tree Suatu Graf Berbobot Dengan Menggunakan Pemrograman Berorientasi Objek." FORISTEK: Forum Teknik Elektro dan Teknologi Informasi 1, no. 2 (September 2011): 70-79.

Purwadi, Ihsan. Penerapan Bayes Network Dalam Penetapan Daerah Tertinggal. Bogor: IPB, 2009. 